\title{
PERSPECTIVES ON LABOR POLYSEMY: THEORETICAL FOUNDATIONS AND STUDY POSSIBILITIES
}

\author{
RENATO K. COLOMBY ${ }^{1}$ \\ (iD https://orcid.org/0000-0002-5013-6913 \\ SILVIA G. DA COSTA \\ (iD) https://orcid.org/0000-0002-4842-2654
}

To cite this paper: Colomby, R. K., \& Costa, S. G. da. (2018). Perspectives on labor polysemy: Theoretical foundations and study possibilities. Revista de Administração Mackenzie, 19(5). doi:10.1590/1678-6971/eRAMG180082

Submission: Apr. 30, 2018. Acceptance: Jul. 16, 2018.

Universidade Federal do Rio Grande do Sul (UFRGS), Porto Alegre, RS, Brazil.

\footnotetext{
(cc) BY 


\section{ABSTRACT}

Purpose: To understand the meaning and meaningfulness of work under different points of view and support the researchers of the subject to reflect on which lens(es) are formulating their research.

Originality/value: The main contribution of the article is in the synthesis and registration of ten categories of analysis of the multiple and possible meaning and meaningfulness of the work, either in isolation or in their connections. This article is in itself a theoretical proposition cooperates for the extension of the literature and is original when indicating ten complementary perspectives for the object of study: physiological, cultural, religious, spiritual, ideological, economic, political, legal, psychological and social.

Design/methodology/approach: This article has a qualitative approach and has as a method a literature review of the narrative type and is based on more than 80 national and international references.

Findings: When analyzed in an integrated way, these perspectives expand the possibilities of contextualization and future researches in the field of the mentioned subject. Finally, it is defended that there is still a long way in the problematization of this phenomenon so central in the life of the individuals and for the society, mainly in what concerns the current context of multiple crises and intense social transformations.

\section{KEYWORDS}

Work. Meaningfulness of work. Meaning of work. Perspectives on work. Polysemy of Work. 


\section{INTRODUCTION}

Work is a phenomenon in constant transformation, which reinvents itself with socio-political-economic changes, making its concept changeable and transdisciplinary. Its recognized research potential keeps it always on the agenda of academic research, garnering the attention of authors of the most different theoretical currents. Despite these differences, there is convergence at one point: the centrality of work in society (Mow, 1987; Morin, 2001; Antunes, 2002; Dejours, 2004).

In view of this centrality, of the current scenario of multiple crises and of the many and profound transformations that the work world undergoes, it is imperative that it be retaken as a priority object of research and reflection (Cattani \& Holzmann, 2011). By understanding that the work also assumes its own characteristics in relation to the social factors present at the time of its analysis (Antunes, 2002) and that each individual can perceive it and give a (new) meaning to it in a singular way, this article presents the multiplicity of perspectives on the work phenomenon so that it can subsidize the complexity of the debates about the theme.

For this, we chose to construct a theoretical essay, considered as a legitimate document in the production of knowledge (Bertero, 2011). The main contribution of this paper is the effort to synthesize and record ten categories of analysis of the multiple and complementary meanings and meaningfulness of work, namely: physiological, cultural, religious, spiritual, ideological, economic, political, legal, psychological and social. These ten categories of analysis represent a form of organization and understanding of the phenomenon in question and do not aim to be a restrictive model.

The theoretical perspectives were elaborated through a literature review of the narrative type. After all, a literature review is an important first step in the construction of scientific knowledge, because "it is through this process that new theories emerge, and gaps and opportunities are recognized for the emergence of research on a specific subject" (Botelho, Cunha, \& Macedo, 2011, p. 123).

The revision of the narrative literature (or also called the traditional bibliographic review method) when compared to the systematic review, is congruent with more open themes, not requiring a rigid protocol for its accomplishment and, as far as the search of sources, the selection of the material is promoted by the authors in a more personal and subjective way based on their ontological and epistemological assumptions (Cordeiro, Oliveira, Renteria, \& Guimarães, 2007). 
Therefore, the ten categories presented in relation to the meanings and meaningfulness of the work were elaborated from the bibliographical searches, the readings, the interpretations and the theoretical propositions of the researchers involved. The focus of this narrative review was to describe the state of the art, from the theoretical point of view, in the light of perspectives not yet explored and, thus, enable the acquisition and updating of knowledge about the referred subject (Rother, 2007).

Thus, in addition to this introduction and a brief report about work, this theoretical essay was organized in ten units that aim to make explicit each of the perspectives found in the review of the literature. The last section was devoted to the final considerations of the paper.

\section{THE MEANING AND MEANINGFULNESS OF THE WORK, ITS CENTRALITY, AND ITS POLYMERIC AND MULTIFACTORED CHARACTER.}

Tolfo and Piccinini (2007) point out that some researchers address the meaning of work (Mow, 1987), while others privilege its meaningfulness (Antunes, 2002), even though several authors (Bendassolli, 2009; Morin, 2001; Mow, 1987) consider meaning and meaningfulness of work synonyms.

Based on a literature review and an etymological analysis of the meaning and meaningfulness of the work performed by the authors, the word meaning can refer to perception, significance, and feeling; while the meaningfulness entry may be related to a sign (symbol, concept) that stands out. Therefore, the meaningfulness of work is understood as the social representation that the task performed has for the worker, for the group of which he is part or for the society. Following this line of reasoning, the meaning of the work goes beyond the individual, collective and social factors of work and is linked to the usefulness of the task(s) performed, the freedom and autonomy for the execution of that task(s) and self-realization, satisfaction, the feeling of personal and professional development.

In summary, it can be understood that the meaningfulness of work is the fruit of the constructions elaborated collectively in a concrete historical, economic and social context. However, the meanings of work are due to individual apprehension of collective meaningfulness in everyday experiences (Tolfo, Coutinho, Almeida, Baasch, \& Cugnier, 2005).

Bendassolli and Gondim (2014, p. 133), emphasizing the interdependence of concepts, conclude that work allows the relation between meaningfulness 
and meanings when constructed in the relationship of the individual with the world, "through the mediation of his activity". Nevertheless, Tolfo, and Piccinini (2007, p. 44) state that the meanings and meaningfulness of work are a "multidimensional construct" and that "there is an unequivocal interdependence between the two".

In turn, a term is called polysemic when it is used with various significances. The word work can thus be understood since it is susceptible to multiple interpretations. Work as the action of man can refer to the implication of physical force and/or intellectual effort to achieve a certain purpose and can also be a transforming activity of nature, a service, profession, trade or occupation (Albornoz, 2008). In summary, work can mean both sources of construction, satisfaction, wealth, material possessions and services useful to human society, as well as slavery, exploitation, suffering, illness, and death (Seligmann-Silva, 1990).

The term "polysemy of work" has already been used by other authors in different contexts, as by Frigotto (2009), who rescues in Marx the discussion of the polysemy of the work category and the class struggle. Moreover, Antunes (2013, p. 100) has also made use and defense of the term in relation to this object of study:

however, contrary to the thesis that advocates the end of work, we are challenged to understand what I have been calling the new polysemy of work, its new morphology, that is, its way of being (to think in ontological terms), whose most visible element is its multifaceted design, as a result of the strong mutations that have shaken the productive world of capital in recent decades (Antunes, 2013, p. 100).

According to Castel (1998), the work is configured as an economic, psychological, cultural, symbolic reference and fundamental support in the social structure. According to Bendassolli (2009), the meaningfulness of the work can be considered plural, fragmented and formed by several influences, without one emphasizing the other, however. For this author, from Mow (1987), the meaningfulness of work can be understood as a set of cognitive and affective aspects, behavioral and macrostructure predispositions.

Lukács $(1978$, p. 4) states that "only work has, in its ontological nature, a clearly transient character". In turn, Dourado, Holanda, Silva, \& Bispo (2009, p. 352) point out that "the interconnections between the economic, political, ideological and psychological instances are what influence the individual phenomenon of attribution of meaning to labor action". 
Fontoura and Rocha-de-Oliveira (2014, p. 2) collaborate with this view, stating that "work is a complex activity that is difficult to conceptualize because of the diversity of objects, events and situations involved and the diversity of meaningfulness it acquires in different historical contexts". In an effort of conceptualization, work is understood here as a central phenomenon in society, inseparable from life as a whole, with multiple dimensions complementary to each other and a universal, changeable and polysemic concept. With this in mind, in the next sections, each dimension of the work will be duly presented.

\subsection{The body influencing work and work influencing the body}

Commonly used in the medical field, the word physiology is a result of the Greek radicals physio (nature) plus logy (study) and can be understood as the science of the normal function of living things (Harper, 2018a). When the history of work is analyzed, it is verified that "any society has defined, with more or less rigidity and exclusivity, spheres of activities that include works and tasks considered appropriate for one gender or the other" (Holzmann, 2011, p. 125). This gender-based division of labor is due to, among other factors, the understanding that men and women have physiological characteristics (innate or acquired) that facilitate the performance of some activities (Hirata \& Kergoat, 2007).

Under this perspective, Taylor (1990) based his studies of times and movements in human anatomy and physiology, together with other elements, to substantiate the RLO (Rational Labor Organization). In the Scientific Administration, by dividing and subdividing work into specific movements for the execution of each task, the author intended to obtain the best "use of the human body" to, among other reasons, reduce fatigue, decrease accidents and increase worker productivity.

Mises (1995, p. 592) sees the work in a physiological focus when he argues that one "can work with the objective of strengthening and speeding up his/her mind and his/her body". On the other hand, Dejours, Dessors, and Desriaux (1993, p. 98) point out that "professional activity is not only a way of earning a living-it is also a form of social insertion where psychic and physical aspects are strongly implicated". Hence, "work can be a factor of deterioration, of aging and of serious illnesses, but it can also be a factor of equilibrium and development" (Dejours, Dessors, \& Desriaux, 1993, p. 98), they complement that "the possibility of the second hypothesis is linked to a work that allows each individual to ally with the physical needs, the desire to perform the task" (Dejours, Dessors, \& Desriaux, 1993, p. 98). 
The physiological perspective of the work phenomenon also includes questions related to the changes that a person can present in the meanings and meaningfulness of the work as a result of some change in their state of health or modification related to the abilities of their body. After all, when the worker becomes ill, "the loss of work capacity puts the internal resource of human activity at risk" (Schlindwein, 2013, p. 431).

In addition to an illness, there is the issue of aging. Even if there is an increase in life expectancy (Instituto Brasileiro de Geografia e Estatística [IBGE], 2016), it is a natural process that affects individuals throughout their lives (Lima, Lopes, Carvalho, \& Melo, 2012), which may vary from individual to individual and from one culture to another (Locatelli \& Fontoura, 2013), Antunes and Alves (2004) denounce the exclusion from the formal labor market of people over 40 years of age. The same authors call attention to contradictory facts such as the exclusion of young people from this same "market" and the early and criminal inclusion of children in the most diverse productive activities.

Still, as examples of this influence of the body on the work, the barriers of access imposed on people with disabilities, to women and to black people can be mentioned. Although there are socio-cultural crossings and a relationship with the other perspectives to be presented, a body-related load can be identified in all these factors.

\subsection{The reflections of the heritage of different cultures in the understanding of work}

The word culture originates from the Latin colere and means to cultivate (Harper, 2018b). In general, Tylor (1920) coined the term culture as a complex that includes knowledge, beliefs, art, morality, law, traditions, and all other habits and abilities acquired by man as a member of society. According to Linton (1970), culture can mean the social and total inheritance of humanity; or even a certain variant of social heritage.

Following this reasoning, Tozatto (2009) affirms that having a job is one of the ways to enroll in a line of membership as heir to a culture and a story passed on to the new generations. After all, culture is made up of a large number of other cultures, which in turn are characteristic of a certain group of individuals (Linton, 1970).

Culture can also be understood as a mark of a certain place by carrying the way we see and represent its traditions, habits, and intergenerational exchanges. Thus, cultural differences can directly influence the relationship 
with work. Each place has its own culture(s) and therefore may handle work in a different way and, in turn, cultural singularities may (in)directly influence people in the perception they attribute to the work.

Similarly, an analysis of the understanding of the meaning and meaningfulness of work - at one geographical point-at different historical moments may also reveal disparities. This may also occur in some professions, and it is possible to verify that, over time, different values have been attributed to certain professions (Colomby, Oltramari, \& Rodrigues, 2018).

On the relation of mutual influence between work and society, Laner (2005) maintains that

the work, while relational social modality, becomes the cause and consequence of an entire culture and its respective social formation. Work is conditioned, thus, by the way a given culture shapes its social relations, contributing through its dynamics to modifying them. It can be affirmed, then, that work, besides being shaped by culture, is also a model of culture (Laner, 2005, p. 65).

According to Colomby et al. (2018), cultural factors can influence the perception of professions that are seen as masculine and others as feminine. In this sense, Kergoat (2001) argues that the conditions in which men and women live are not products of biological destiny, but are, above all, social constructions. For Varikas (1992), these relations imply antagonisms or conflicts related to domination and oppression, and crosses the whole of society, articulating with the other social relations.

\subsection{The work in the religious point of view: from punishment to prosperity}

Religion can be understood as a systematized, life-giving, organized, institutionalized, and communitarian worldview of seeking something transcendent to the human being in which religious formalized practices such as rituals, prayers, dogmas, norms, and teachings are present (Mitroff \& Denton, 1999; Bell \& Taylor, 2004; Arribas, 2008). Above all, religion is related to the acclamations of one or another faith tradition and with an aspect of which some form of paradise or redemption is accepted (Gyatso, 2000). It is important to emphasize that conceptions in relation to work have always had and still have a religious influence. 
From the Catholic condemnation directed to Adam and Eve in the expulsion of paradise to divine redemption through the effort offered by the Protestant ethic, work continues to occupy a central place as a category of social analysis. According to Bendassolli (2009), in the medieval conception, work went from punishment to the salvation of the man. In the biblical passage, "by the sweat of your face you shall eat bread," Adam and Eve are expelled from paradise and begin to have work as obligation and penance after having committed the "original sin" of eating the forbidden fruit. Before the ban, work had the meaning of sharing between a man and the divine work (Laner, 2005; Bendassolli, 2009).

After this medieval conception, according to Bendassolli (2009), Saint Augustine retakes the meaning of work as a voluntary act and result of divine orders. Work for the Judeo-Christian tradition was rigid, disciplined, and considered a way for man's salvation and approximation with God. The monks occupied most of their time with work in order to avoid idleness and the possibilities of vices and temptations. In addition, work also atoned sins and punished the body (Laner, 2005).

With the growth of commerce, work is seen no longer as penance, but as salvation. According to the Protestant ethic, launched by Martin Luther and later followed by John Calvin, "intense work, carried out with zeal and selfdenial, would be equivalent to the cultivation of virtue" (Laner, 2005, p. 42).

Based on this, it can be seen that religions have influenced the way of seeing work, not only on the part of its followers but also on society as a whole. After all, as Bourdieu (1992, p. 46) argues, religion is a structured symbolic system that can "assume an ideological function, a practical and political function of absolutizing the relative and legitimating of the arbitrary" and thus legitimates interests of certain dominant social groups.

\subsection{The spiritual perspective: between transcendence and labor activity}

Although religiosity and spirituality may be related, they cannot be considered synonyms. The first can serve as a way for the second, just as there can be a spiritual search without the involvement of religion. Spirituality is related to the qualities of the human spirit, such as love and compassion, patience, tolerance, forgiveness, contentment, a sense of responsibility, and a feeling of harmony that bring happiness both to oneself and to others (Venzke, 2015). 
Spirituality is a universal human feeling at the same time as it is characterized as a more personal, private and inclusive way with components related to inner life, meaningful work and the relationship with the community (Karakas, 2010). Wigglesworth (2014) complements that spirituality is an innate human need, that is, individuals feel the need to connect to something greater, something that they consider to be divine or of exceptional nobility. Carroll (2004) believes that spirituality refers to the condition of being of the spirit, which is the part of us that animates us, gives life and transcendence. Hence, "the spiritual concept of life refers to the mode of consciousness in which the individual experiences a sense of belonging and connection with the cosmos as a whole" (Venzke, 2015, p. 38).

These visions can influence professional choices as well as the relationship people establish with each other and with work organizations. Pierre Teilhard de Chardin (1988-1955) states that we are not human beings living a spiritual experience, we are spiritual beings living a human experience.

Giacalone and Jurkiewicz (2010) point out that, there is increasingly scientific evidence that spirituality in work results in positive effects for workers, such as increased happiness, serenity, job satisfaction and commitment. Krishnakumarand Neck (2002) suggest that the encouragement of spirituality in the workplace can lead to benefits in the areas of creativity, honesty, personal fulfillment and commitment, which will eventually lead to increased organizational performance. In believing that spiritual intelligence can improve and give meaning to work, Zohar (2012) proposes that organizations work towards the development of each individual's ability to access their highest meanings, values, and purposes, incorporating them into their way of life, to a richer and more creative existence.

Therefore, work can be the activity in which a person can develop in totality, connecting with their authentic values, to others and to the transcendent. Added to this, the person perceiving themselves as part of a larger whole can act in a way that positively impacts the whole, and can be positively impacted by this whole. Thus, change can begin within the worker and expand outwardly with the understanding of individual values and values of the institution, relating them to the values of society (Venzke, 2015).

\subsection{Ideology(-ies): work as a source of exploration and/or emancipation}

The term ideology is a complex concept with a great wealth of meanings (Eagleton, 1997). According to Morais and Paes (2010), in the literature, 
ideology is studied through two perspectives: micro and macro. In the first, it is understood as a worldview, in the sense that it is "a relatively well systematized set of categories that provide a framework for the belief, perception, and conduct of a group of individuals" (Eagleton, 1997, p. 49). In the last, we have the view of class conflicts, in a world produced by the owners and by the capitalist system, in which the organization appears exclusively as a place for the establishment of social relations of production (Enriquez, 1997).

Horochovski and Taylor (2001) understand ideology as something that exercises a kind of standardization of the desires and behaviors of individuals who share it. Ideology, then, is a determining factor in how a group sees and interprets reality; it is a shared way of understanding and thinking the world and can be illustrated as an apparatus that directly interferes with the consciousness of individuals, guiding their thoughts and behaviors towards a conformity with the ideas of the group (Morais \& Paes, 2010).

Althusser (1998) argues that ideology is embodied in institutional practices and can reinforce or perpetuate different forms of domination. In addition, ideology has a relevant influence on how work is perceived and therefore realized in society (Eagleton, 1997). Dourado et al. (2009) emphasize that "the way work is viewed, and its meaning for people are strongly influenced by the ideology that guides it" (p. 353), and therefore this phenomenon is seen as, among other things, a blessing, a punishment or a form of capital accumulation.

For Marx (1989), in a capitalist production society, work consists of a process in which the product of labor has a use value and no longer belongs to the man who performed it, but to the one who bought its workforce as an exchange value. For Althusser (1998, p. 58), the worker is a spare part externally multiplied through ideological mechanisms: "the school (but also other State institutions, such as the Church and other apparatuses such as the Army) teaches know-how, but in ways that ensures submission to the dominant ideology or mastery of its practice".

According to Cattani and Holzmann (2011), in the capitalist society, wage-labor is a typical form of labor relation that historically particularizes it. In opposition to capitalism, in which the situation of man is determined by social origin and wealth, in socialist society, the situation of man is determined only by work and personal faculties, and work must be free from exploitation (Academia de Ciências da URSS, 1961). In this sense, Marx (2004, p. 82) is categorical in stating that "work produces wonders for the rich but produces deprivation for the worker". And the work, in its dialectical character, under capital is a contradictory and paradoxical 
process, because the same work that is a means of humanization is also a source of sacrifice. (Ferraz, Maciel \& Sousa, 2015).

Mises (1995, p. 21) states that the man "wants to live in abundance", that the "vast majority" of people "prefer life to death, and wealth to poverty". People who agree with this worldview defend the businessman or entrepreneur as a hero and not as an explorer; and think of meritocracy as a form of justice. We can see this in Hayek's (1990, p. 123) words: "It is rare to find independence of spirit or strength of character among those who do not trust their ability to make their own way". In this sense, Mises (1995, p. 594) states that "the worker rejoices because he acquires self-respect and awareness that he is able to support himself and his family without dependence on the mercy of others".

Given the above, ideology is understood as a historical, social and political movement that conceals reality as a way of maintaining economic exploitation, social inequality and political domination (Chauí, 2017).

\subsection{Economic perspective: work as a source of income and consumption}

Economy is a word of Greek origin that originally meant home management (Harper, 2018c). Currently, it can be understood as a science that studies the production, circulation, and consumption of wealth. Regarding the work phenomenon, from Taylor's homo economicus to the present day, material rewards are emphasized as central elements in the motivation for the work activity and in the increase of productivity.

If a historical analysis was carried out in relation to the primitive modes of production, one realizes that the work was done collectively and was associated with the struggle for survival in the production of subsistence. The organization of rural labor was cooperative and used rudimentary techniques: the peasant was in charge of agricultural activities, hunting, fishing, animal husbandry and handicrafts, which were domestic activities (Oliveira, 1991).

As of the $17^{\text {th }}$ century, the germination of the first seeds of the capitalist mode of production led to the valorization of labor as an implementor of economic growth and wealth. With the rise of urban industrial society, labor was monetarized and the workforce marketed (Dourado et al., 2009). In the industrial age, the valorization of labor continues to grow, becoming a symbol of man's freedom to transform nature and society. This revolution in thought frees individuals from the old ties to the earth, for each one becomes a free worker, who offers strength and intellect to anyone who employs him/ her. Therefore, the individuals who do not work are parasites, delinquents 
and useless (Enriquez, 1999). After World War II, "wage labor has become a source of workers' security, making it possible to organize their lives, to project their future in the least, with expectations of social advancement for their children" (Cattani \& Holzmann, 2011, pp. 7-8).

Ferraz, Maciel and Sousa (2015, p. 8) add that "wages are nothing more than the equivalent value in money of the value of the (re)production of the workforce and, in these terms, in capital, the human being works to reproduce the merchandise that he/she sells". However, even when used in its economic sense (paid work) and restricted to the context of formal organizations, it's diversified, ambiguous and complex aspect remains (Cattani, 2000).

In this discussion, Rifkin (1995, p. 17) inserts the problematic that "millions of workers have already been definitively eliminated from the economic process; functions and categories of work have already been reduced, restructured or disappeared". According to the author, redefining opportunities and responsibilities for millions of people in a society without formal employment is the most pressing social issue of our time. Once "from the outset, civilization has been structured, in large part, according to the concept of work. From the Paleolithic hunter/harvester and the Neolithic farmer to the medieval craftsman and assembly-line worker" of the last century, "work has been an integral part of daily existence" (Rifkin, 1995, p. 3).

\subsection{The work in the political perspective: the structuring power of organizations}

Once politics, like work, is a concept with different interpretations, it is sought here to understand it as a form of social organization or as the representation of a management model in which power relations are always present (Harper, 2018d). Therefore, the discussion about work as a social organizer is quite old, and several authors dialogue their perceptions on this subject.

Our civilization is born, develops and progresses in work, that is, we live in an organizational society (Presthus, 1962). Etzioni (1964) complements that we live in a world of organizations and exemplifies:

we are born in organizations, we are educated by organizations, and most of us spend much time of our lives working for organizations. We spend a lot of our time paying for leisure, playing and praying in organizations. Most of us will die in an organization, and when it's time for burial, the largest organization of all—the state-must grant official permission (Etzioni, 1964, p. 1). 
For Marcuse (1969), organizations have a fundamental and particularly repressive role within the system; in addition, it is in organizations that alienated labor is exploited in the name of the rationality of this same system. Enriquez (1999), work has become a fundamentally integrating element, allowing society to weaken or reinforce social ties. Nevertheless, in the struggle against the power of private interests, work can play an essential role in shaping the public space. After all, work is the main locus in which the learning of democracy takes place. However, if the renewal of living together fails, then work can become a dangerous force for the destruction of democracy and the diffusion of cynicism and the one-for-oneself. In this way, work plays an important role, positively or negatively, from the political point of view (Dejours, 2004).

According to Mercure and Spurk (2005, p. 7), "well before the French Revolution or the Bolshevik Revolution, work showed all its conflicting and contradictory power in the slave revolts and in the peasant wars of societies that had nothing of modern". These authors combine work as such a structuring component of social life, that it was not possible to go unnoticed, even if its form was morally and socially detestable as slavery, servility and certain types of wage labor.

Therefore, it is necessary to understand that work, as it is exercised today, has a political-functional role in the current social context, that is, the way it is performed and controlled derives from a relation of power inherent to the capital-labor relation and it is configured as a measure created by the system itself to maintain its power of domination.

Management has found ways to deal with the essential conflict between individual and organization, proposing increasingly sophisticated managerial practices of individual control at work, in pursuit of progressive performance results (Dourado et al., 2009). Among managerial practices, one points to flexibility, a striking feature of "new capitalism", which implies individual freedom, but actually produces new forms of power and control (Sennett, 2009). In addition to these "invisible mechanisms", one can point to "visible mechanisms" and the transition from management through orders to management through regulations as forms that are impacting the understanding and accomplishment of work (Pagès et al., 2006).

\subsection{Work as synonyms of employment and the warranties of law}

For Carreteiro (2006), social rights in Brazil were, until recently, directly linked to the issue of work, that is, to the labor status of the individual. 
Tozatto (2009) emphasizes that, in Brazil, citizenship refers to social rights that are tied, for a long time and erroneously, only to the paid worker with registration in the workbook.

Thus, dealing with the legal dimension of work is also to put into question what refers to its formal and informal character. dimension of work is also to put into question what refers to its formal and informal character. The term "formal" covers Brazilian workers with a contract guaranteeing social rights through Consolidation of Labor Laws in Brazil. The informal Brazilian workers don't have the protection of the work laws and often any kind of work contract. Piccinini, Oliveira, and Rubenich (2006) corroborate this view by stating that the signed work permit represents the proof of the employment relationship, strengthening or ensuring to the worker all the benefits of the Brazilian labor legislation. This concept is used by the IBGE that considers a "formal" worker the employee who has a signed workbook, and informal the worker without a signed workbook and those self-employed.

According to Santos (2008), informal work in Brazil has intensified to such an extent since the 1990s that today it is a characteristic feature of the Brazilian labor market and absorbs a large part of the population excluded from the formal market. Toni (2011) clarifies informality as the small urban production, developed in the loopholes of the activities of the capitalist nucleus, being able to associate to it the low or nonexistent formalization, either of the activity itself or of the forms of labor insertion. In operational terms, the core category is self-employed, and others may be added, such as a family business owner and unpaid family worker, or even an employee without a signed work permit and a domestic employee.

For some authors, the precariousness is directly related to the informality of the work. For others, one may have a formal and precarious work, but hardly an informal and unprecarious work. According to Mattoso (1999), the precariousness of working conditions is related to the expansion of waged work without a workbook and independent work (self-employment), by the increase of work for a fixed time, with no fixed income and part-time. According to his words, "In general, it is identified by the absence of social security contributions and, therefore, without the right to retirement" (Mattoso, 1999, p. 8).

Holzmann (2006) demonstrates, through an analysis of statistical data from IBGE (Brazilian Institute of Geography and Statistics), an increase in informality and an intensification of the precariousness of work in Brazil, and complements that 
the employer-signed workbook is much more than the guarantee of access to the benefits of labor legislation for the Brazilian worker. It represents, in the worker's imaginary and daily experience, the certification of his/her citizenship and the possibility of defending his/her dignity as such. The possession of this document distinguishes the citizen from that individual who does not build his respectability through work, the non-citizen (Holzmann, 2006, pp. 74-75).

In addition, Piccinini, Oliveira and Rubenich (2006) affirm that as social protection is strongly linked to formal work, its financing and its effectiveness depend on the maintenance of long-term employment relationships, since a large part of the resources that support social security programs stems from the contribution of companies and employees calculated on payroll and wages.

Finally, it should be pointed out that the high levels of unemployment and the dismantling of social protection under the responsibility of the State have pushed workers of different profiles into informality and precariousness (Toni, 2003). In addition, recent changes in labor rights and access to labor justice laws, with an absolute disfigurement of the Consolidation of Labor Laws, are predicting even more unstable and conflicting labor relations (Sabatovski, 2017).

\subsection{Mental health, subjectivity and symbolic content of work}

In the psychological instance, work can be a form of identity, the process of self-knowledge, a way to maintain one's mental health, the conjugation of the verb to be in its singularity. Processes such as mobilization of intelligence, recognition, and gratification, rather than related to the performance of work, are linked to the constitution of identity and subjectivity. This is why, for Dejours (2004, p. 14), work can be understood as "a central element in promoting a person's psychic development and constitution of identity".

In a survey conducted by Morin (2001), more than $80 \%$ of participants answered that-even if they had the money to live the rest of their lives comfortably without work-they would continue to work. For the author, among the reasons for this response is the desire of people to avoid boredom, to have something to do and to find a purpose in their lives. In this sense, Clot (2011) considers work as a permanent activity to recreate new ways of living.

It is also possible to use the concept of sublimation as an instrument for understanding work situations. The underlying idea is that these drives of the individual, which should lead to sexual relations, are redirected to work. 
For sublimation to occur in work activity, it is necessary that psychic, ontogenetic, organizational, ethical and social conditions be fulfilled. Repetitive work eliminates this possibility of sublimation (Merlo, 2007).

According to Clot (2007), work not only retains its psychological function in the personal life but also develops it, insofar as the work has a cognitive psychological function related to the individual's activity, thought, language and emotions. Enriquez (as cited in Araújo \& Carreteiro, 2001, p. 58) states that "work in our society is the privileged way make things (however small), to exist, to have or to think of having an identity. Work is currently the best method to overcome madness".

Gaulejac (2001) points out that in addition to psychic factors, we cannot think about the issue of the individual without inscribing him/her to the social universe. The author clarifies that "if the individual is the product of a story, it condenses, on the one hand, the set of socio-historical factors that intervene in the process of socialization and, on the other, the set of intrapsychic factors that determine his/her personality" (Gaulejac, 2001, p. 41). The social facet linked to the work phenomenon, however much it may be directly associated with the individual, deserves deepening and therefore the next section is dedicated to this perspective.

\subsection{The social dimension: the self-worker under the look of the other}

Work is an essential factor in human life and an important means for satisfying psychological and social needs (Dejours, 2004). Psychological, because it is about subjective issues that relate to individual issues that reflect the personal history of each one and social because it is shared by a set of people (Souza \& Tolfo, 2009). After all,

the development of identity and the transformation of suffering into pleasure are directly related to the other's gaze and to the mechanisms of recognition arising from this look. When the recognition of labor does not exist, the consequent devaluation reaches other spaces of the daily life of the workers, contaminating the time of nonwork. (Dejours, 2004, p. 33).

Morin (2001) also presents work as a way of relating to others and their desire to be linked through the activity they perform. The work has a representative role in ensuring citizenship and can be seen as a symbol that 
expresses the connection between different people, giving the sense of collectivity. Dejours (2004, p. 30) understands work as "the greatest factor of meaning production for social integration".

For Bendassolli and Soboll (2011, p. 11), "groups, organizations and institutions are mediators of individuals' personal lives and are created, governed and transformed by them". Castel (1998) emphasizes that work is the matrix of social integration, but it can also be the cause of the fragmentation of these relations. The author observes the direct relation that is established between the process of precarization of the labor relations and the consequent social vulnerability to which the individual is exposed. According to him, due to the loss of social status and the deterioration of the wage situation, unemployment changes family strategies and weakens these relationships.

According to Tozatto (2009), the work is assimilated as life, and, consequently, its lack can provoke anguish of psychic and social death. Tavares (2014) defends the sense of social belonging as a basic and universal right.

After all, for Dejours (2004, p. 32), "it is from the gaze of others that we constitute ourselves as individuals". According to him, it is precisely in relation to the other that we recognize ourselves in the process of seeking similarities and differences; the daily relations are what allow the construction of the individual and social identity, from material and affective exchanges, making the subject, throughout his life, constitute his singularity in the midst of differences. In adult life, the workspace is the privileged stage of these exchanges, and it is the one that allows the confrontation between the external world and the internal world of the worker. Thus, if on the one hand the world of work generates suffering (insofar as it confronts people with external impositions), on the other hand, it is also the central opportunity for growth and adult psychic development (Dejours, 2004).

We conclude that, besides the psychological character, work is an important means to satisfy the social needs and the construction of the social bond. In other words, "working is not just about producing: working is still living together" (Dejours, 2004, p. 18).

\section{FINAL CONSIDERATIONS}

Each presented perspective emphasizes a predominant point of view for the understanding of the work phenomenon. Each dimension can be linked more to the individual in his/her physiological, subjective or collective 
aspects; society in its most normative aspects; institutions in their political role either in the organization of society or in the mediation of conflicts; or the dominant system and ideology (including economic and religious perceptions); or the spirituality that guides them. All of the approaches presented here are complementary and need to be viewed systemically.

That is, upon reflecting on work, it is suggested to think of it in its subjectivity, to relate it socially, to question the cultural and ideological influence that may be hidden in its relations, including relations of power. Also, do not forget that for different people in different phases of their lives, work can change from needs restricted to survival to spheres more linked to self-realization.

The perspectives presented are not intended to limit the lenses of those who seek to problematize the phenomenon of work, but rather to consider the possibility of a critical, faithful and legitimate view of that word that sometimes ends up being vulgarized and used without theoretical deepening or reflection of its use and centrality. In addressing ten views on this phenomenon, we hope to recognize its richness and plurality of content, as well as its uniqueness.

We encourage future investigations with this theme to amplify it since each perspective has in itself a world of possibilities. When a broad theoretical framework is chosen, the references are imbricated from a narrow theoretical base of epistemological distinctions, sometimes presenting a strong difficulty of interlocution. However, it is argued that breaking these barriers is precisely the contemporary challenge of the social sciences.

In addition, we suggest investigating 1 . The impact of virtualization of relations and digital work in the configuration of the work, perhaps as another perspective for analyzing the phenomenon, in addition to the following possibilities: 2. Family-work relations and conflicts, 3. Work as art and leisure, and 4. Work from a philosophical perspective.

The main contribution of this article is in the synthesis and registration of ten categories of analysis of the multiple and possible meaning and meaningfulness of the work, either in isolation or in their connections. Because it is a phenomenon so present, changeable, dynamic, central and impactful to individuals and society, the relationship of categories herein presented is not intended to be definitive or finished and has no predetermined order. 


\section{PERSPECTIVAS ACERCA DA POLISSEMIA DO TRABALHO: FUNDAMENTOS TEÓRICOS E POSSIBILIDADES DE ESTUDO}

\section{RESUMO}

Objetivo: Compreender os sentidos e significados do trabalho sob diferentes olhares e apoiar os pesquisadores do tema a refletirem sobre qual(is) lente(s) estão formulando suas pesquisas.

Originalidade/relevância: A principal contribuição do artigo se encontra na síntese e registro de dez categorias de análise dos múltiplos e possíveis sentidos e significados do trabalho, seja de forma isolada, seja em suas conexões. Este artigo é em si uma proposição teórica, coopera para a extensão da literatura e é original ao indicar dez perspectivas complementares para o objeto de estudo: fisiológica, cultural, religiosa, espiritual, ideológica, econômica, política, legal, psicológica e social.

Principais aspectos metodológicos: Este artigo tem uma abordagem qualitativa, tem como método uma revisão da literatura do tipo narrativa e apoia-se em mais de 80 referências nacionais e internacionais.

Síntese dos principais resultados: Ao serem analisadas de maneira integrada, essas perspectivas ampliam as possibilidades de contextualização e futuras pesquisas no campo do referido tema. Por fim, defende-se que ainda há um longo caminho na problematização desse fenômeno tão central na vida dos indivíduos e para a sociedade, principalmente no que tange ao contexto atual de policrise e intensas transformações sociais.

\section{PALAVRAS-CHAVE}

Trabalho. Significados do trabalho. Sentidos do trabalho. Perspectivas sobre o trabalho. Polissemia do trabalho.

\section{REFERENCES}

Academia de Ciências da URSS. (1961). Manual de Economia Política (J. Gorender \& J. de Almeida, Trans.). Rio de Janeiro, RJ: Vitória. 
Albornoz, S. (2008). O que é trabalho. São Paulo, SP: Brasiliense.

Althusser, L. (1998). Aparelhos ideológicos do Estado. Rio de Janeiro, RJ: Graal.

Antunes, R. (2013, October). A nova morfologia do trabalho. Revista Jurídica UniSEB, 3(3), 93-103.

Antunes, R. (2002). Os sentidos do trabalho: Ensaio sobre a afirmação e negação do trabalho. São Paulo, SP: Boitempo.

Antunes, R., \& Alves, G. (2004). As mutações no mundo do trabalho na era da mundialização do capital. Educação E Sociedade, 25(87).

Araújo, J. N. G., \& Carreteiro, T. C. (2001). Cenários sociais e uma abordagem clínica. São Paulo, SP: Editora Escuta.

Arribas, C. G. (2008). Afinal, espiritismo é religião? A doutrina espírita na formação da diversidade religiosa brasileira (Master's thesis). Retrieved from http://www.teses.usp.br/teses/disponiveis/8/8132/tde-05012009-1713 47/pt-br.php

Bell, E., \& Taylor, S. (2004). A exaltação do trabalho: O poder pastoral e a ética do trabalho na nova era. Revista de Administração de Empresas, 44(2), 64-78.

Bendassolli, P. F. (2009). Psicologia e trabalho: Apropriações e significados. São Paulo, SP: Cengage Learning.

Bendassolli, P. F., \& Gondim, S. M. (2014). Significados, sentidos e função psicológica do trabalho: Discutindo essa tríade conceitual e seus desafios metodológicos. Avances en psicología latinoamericana, 32(1), 131-147.

Bendassolli, P. F., \& Soboll, L. A. P. (2011). Introdução às clínicas do trabalho: Aportes teóricos, pressupostos e aplicações. In P. F. Bendassolli \& L. A. P. Soboll (Org.), Clínicas do trabalho: Novas perspectivas para a compreensão do trabalho na atualidade. São Paulo, SP: Atlas.

Bertero, C. O. (2011). Réplica 2 - O Que é um Ensaio Teórico? Réplica a Francis Kanashiro Meneghetti. RAC-Revista de Administração Contemporânea, 15(2).

Botelho, L. L. R., Cunha, C. C. de A., \& Macedo, M. (2011). O método da revisão integrativa nos estudos organizacionais. Gestão e sociedade, 5(11), 121-136.

Bourdieu, P. (1992). A economia das trocas simbólicas. São Paulo, SP: Perspectiva. Carreteiro, T. C. (2006). O trabalho na vida do jovem: Perspectivas diferentes (Depoimento ao Observatório Jovem). Retrieved from http://www.uff.br 
Carroll, J. (2004). Sustainability and spirituality. Albany, NY: State University of New York Press.

Castel, R. (1998). As metamorfoses da questão social: Uma crônica do salário. Petrópolis, RJ: Vozes.

Cattani, A. D. (2000). Trabalho e autonomia ( $2^{\text {nd }}$ ed.). Petrópolis, RJ: Vozes.

Cattani, A. D., \& Holzmann, L. (2011). Dicionário de trabalho e tecnologia $\left(2^{\text {nd }}\right.$ ed.). Porto Alegre, RS: Editora Zouk.

Chauí, M. (2017). O que é ideologia. São Paulo, SP: Brasiliense.

Clot, Y. (2007). A função psicológica do trabalho. São Paulo, SP: Vozes.

Clot, Y. (2011). Clínica do trabalho e clínica da atividade. In Bendassolli, P. F. \& Soboll, L. A. P. Clínicas do trabalho: Novas perspectivas para a compreensão do trabalho na atualidade. São Paulo, SP: Atlas.

Colomby, R. K., Oltramari, A. P., \& Rodrigues, M. B. (2018). Integrating perspectives: Proposal for the analysis of work as a multifaceted phenomenon. Revista de Gestão, 25(1), 65-83.

Cordeiro, A. M., Oliveira, G. M. de., Rentería, J. M., \& Guimarães, C. A. (2007). Revisão sistemática: Uma revisão narrativa. Revista do Colégio Brasileiro de Cirurgiões, 34(6), 428-431.

Dejours, C. (2004). Da psicopatologia à psicodinâmica do trabalho (F. Soudant, Trasl.). In S. Lancman \& L. I. Sznelwar (Orgs.). Rio de Janeiro, RJ: Fiocruz.

Dejours, C., Dessors, D., \& Desriaux, F. (1993). Por um trabalho, fator de equilíbrio. Revista de Administração de empresas, 33 (3), 98-104.

Dourado, D. P., Holanda, L. A., Silva, M. M. M., \& Bispo, D. A. (2009). Sobre o sentido do trabalho fora do enclave de mercado. Cadernos EBAPE, 7(2).

Eagleton, T. (1997). Ideologia. São Paulo, SP: Boitempo.

Enriquez, E. (1999). Perda do trabalho, perda da identidade. In M. R. Nabuco \& N. A. Carvalho (Orgs.), Relações de trabalho contemporâneas. Belo Horizonte, MG: Instituto de Relações do Trabalho da PUC Minas.

Enriquez, E. (1997). A organização em análise. Petrópolis, RJ: Vozes.

Etzioni, A. (1964). Modern organizations. Englewood Cliffs, NJ: Pretince-Hall.

Ferraz, D. L. S., Maciel, J. A., \& Sousa, R. R. (2015). Representações sociais sobre ser trabalhador terceirizado e a precarização do trabalho. Paper presented at the fifith meeting of Gestão de Pessoas e Relações de Trabalho ENANPAD, Salvador, BA.

Fontoura, S., \& Rocha-De-Oliveira, S. (2014). A construção social do(s) mercado(s) de trabalho: Espaços de lutas de classe, gênero e idade. Paper presented at the eighth meeting of Estudos Organizacionais da Anpad, Gramado, RS. 
Frigotto, G. (2009). A polissemia da categoria trabalho e a batalha das ideias nas sociedades de classe. Revista Brasileira de Educação, 14(40), 168-194.

Gaulejac, V. (2001). Psicossociologia e sociologia clínica. In J. N. Araujo \& T. C. Carreteiro (Orgs.), Cenários sociais e abordagem clínica. São Paulo, SP: Escuta.

Giacalone, R. A., \& Jurkiewicz, C. L. (2010). Handbook of workplace spirituality and organizational performance ( $2^{\text {nd }}$ ed.). Armonk, NY: Sharpe.

Gyatso, T. (2000). Uma ética para o novo milênio ( $7^{\text {th }}$ ed.). Rio de Janeiro, RJ: Sextante.

Hayek, F. A. (1990). O caminho da servidão (5 ${ }^{\text {th }}$ ed.) São Paulo, SP: Instituto Liberal.

Harper, D. (2018a). Physiology (n.). Online Etymology Dictionary. Retrieved from https://www.etymonline.com/word/physiology\#etymonline_v_ 14919

Harper, D. (2018b). Culture (n.). Online Etymology Dictionary. Retrieved from https://www.etymonline.com/word/culture\#etymonline_v_452

Harper, D. (2018c). Economy (n.). Online Etymology Dictionary. Retrieved from https://www.etymonline.com/word/economy\#etymonline_v_980

Harper, D. (2018d). Politics (n.). Online Etymology Dictionary. Retrieved from https://www.etymonline.com/word/politics\#etymonline_v_17576

Hirata, H., \& Kergoat, D. (2007). Novas configurações da divisão sexual do trabalho (F. Murad, Trans.). Cadernos de Pesquisa, 37(132), 595-609.

Holzmann, L. (2011). Divisão social do trabalho. In A. D. Cattani (Org.), Trabalho e tecnologia: Dicionário crítico (pp. 64-67). Petrópolis, RJ: Vozes.

Holzmann, L. (2006). A dimensão do trabalho precário no Brasil no início XXI. In V. C. Piccinini, L. Holzmann, I. Kovács, \& V. N. Guimarães (Orgs.), O mosaico do trabalho na sociedade contemporânea: Persistências e inovações. Porto Alegre, RS: Editora da UFRGS.

Horochovski, R. R., \& Taylor, C. R. (2001). A estruturação do sujeito nas instituições e organizações: Aspectos inconscientes no cotidiano organizacional. Revista Spei, 2(2), 37-47.

Instituto Brasileiro de Geografia e Estatística. (2016). Tábua completa de mortalidade para o Brasil: Breve análise da evolução da mortalidade no Brasil-2015. Retrieved from ftp://ftp.ibge.gov.br/Tabuas_Completas_de_Mortalidade/ Tabuas_Completas_de_Mortalidade_2015/tabua_de_mortalidade_analise. pdf 
Karakas, F. (2010). Spirituality and performance in organizations: A literature review. Journal of Business Ethics, 94, 89-106.

Kergoat, D. (2001). Le rapport social de sexe: De la reproduction des rapports sociaux à leur subversion. Reveu Actuel Marx, (30), 85-100.

Krishnakumar, S., \& Neck, C. P. (2002). The "what", "why" and "how" of spirituality in the workplace. Journal of Managerial Psychology, 17(3), 153-164.

Laner, A. S. (2005). Psicologia e trabalho na história: da apropriação do tempo à busca da felicidade. Ijuí, RS: Editora Unijuí.

Lima, O. B. A., Lopes, M. E. L., Carvalho, G. D. A., \& Melo, V. C. (2012). O idoso frente ao processo de envelhecimento: Produção científica em periódicos online no âmbito da Saúde. Paper presented at de $15^{\text {th }}$ Brazilian congress of the Conselhos de Enfermagem (CBCENF), Fortaleza, CE.

Linton, R. (1970). O Homem: Uma introdução à antropologia. São Paulo, SP: Martins.

Locatelli, P. A. P. C., \& Fontoura, D. S. (2013). Envelhecimento populacional e os estudos em administração. Gestão e Sociedade, 7(17).

Lukács, G. (1978). The ontology of social being. London, UK: Merlin.

Marcuse, H. (1969). O fim da utopia. São Paulo, SP: Paz e Terra.

Marx, K. (2004). Manuscritos econômico-filosóficos. São Paulo, SP: Boitempo.

Marx, K. (1989). O capital: Crítica da economia política-Livro primeiro: O processo de produção do capital (Vol. 1, $13^{\text {rd }}$ ed.). Rio de Janeiro, RJ: Editora Bertrand Brasil S.A.

Mattoso, J. (1999). O Brasil desempregado: Como foram destruídos mais de 3 milhões de empregos nos anos 90. São Paulo, SP: Fundação Perseu Abramo.

Mercure, D., \& Spurk, J. (2005). O trabalho na história do pensamento ocidental. Petrópolis, RJ: Vozes.

Merlo, A. R. C. (2007). Psicodinâmica do trabalho. In M. G. de Jacques \& W. Codo (Org.), Saúde Mental \& Trabalho: Leituras ( $3^{\text {rd }}$ ed.). Petrópolis, RJ: Vozes.

Mises, L. V. (1995). Ação humana: Um tratado de economia (D. Stewart Jr., Trans.) Rio de Janeiro, RJ: Instituto Liberal.

Mitroff, I. I. \& Denton, E. A. (1999). A study of spirituality in the workplace. MIT Sloan Management, Review, 40(4), 83-92.

Morais, L. L. P., \& Paes. P. A. P. (2010). Identificação ou resistência? Uma análise da constituição subjetiva do policial. Revista de Administração Contemporânea, 14(4), 633-650. 
Morin, E. M. (2001). Os sentidos do trabalho. Revista de administração de empresas-RAE, 41(3), 8-18.

Mow (1987). International research team. London: Academic Press.

Oliveira, C. R. (1991). História do trabalho. São Paulo, SP: Ática.

Pagès, M., Gaulejac, V., Bonetti, M., \& Descendre, D. (2006). O poder das organizações. São Paulo, SP: Atlas.

Piccinini, V. C., Oliveira, S. R., \& Rubenich, N. V. (2006). Formal, flexível ou informal? Reflexões sobre o trabalho no Brasil. In V. Piccini, L. Holzmann, I. Kovács, \& V. N. Guimarães (Org.), O mosaico do trabalho na sociedade contemporânea: Persistências e inovações. Porto Alegre, RS: Editora da UFRGS.

Presthus, R. (1962). The organizational society. New York, NY: Knopf.

Rifkin, J. (1995). O fim dos empregos. São Paulo, SP: Makron Books.

Rother, E. T. (2007). Revisão sistemática X revisão narrativa. Acta Paulista de Enfermagem, 20(2). doi:10.1590/S0103-21002007000200001

Sabatovski, E. (2017, July). Reforma trabalhista 2017. Legjur. Retrieved from https://www.legjur.com/noticias/3487/reforma-trabalhista-2017-noticias

Santos, G. P. G. (2008). Desemprego, informalidade e precariedade: A situação do mercado de trabalho no Brasil pós 1990. Pro-Prosições,19(2), 151-161.

Schlindwein, V. L. D. C. (2013). Histórias de vida marcadas por humilhação, assédio moral e adoecimento no trabalho. Psicologia \& Sociedade, 25(2), 430-439.

Sennett, R. (2009). A corrosão do caráter: Consequências pessoais do trabalho no novo capitalismo $\left(14^{\text {th }}\right.$ ed.). Rio de Janeiro, RJ: Record.

Seligmann-Silva, E. (1990). Saúde mental e trabalho. In S. A. Tundis, N. R. Costa (Orgs.), Cidadania e loucura: Políticas de saúde mental no Brasil ( $2^{\text {nd }}$ ed., pp. 217-288). Rio de Janeiro, RJ: Vozes.

Souza, R. M. B., \& Tolfo, S. R. (2009). Significados atribuídos ao trabalho em condições precárias: um estudo com feirantes do largo da ordem de Curitiba, PR. Proceedings of the $15^{\text {th }}$ meeting of ABRAPSO.

Taylor, F. W. (1990). Princípios da administração científica. Principles of Scientific Management. São Paulo: Atlas.

Tavares, R. C. (2014). O sentimento de pertencimento social como um direito básico e universal. Cadernos de Pesquisa Interdisciplinar em Ciências Humanas, 15(106), 179-201. 
Toni, M. (2011). Fim do trabalho versus centralidade do trabalho. In A. D. Cattani \& L. Holzmann (Org.), Dicionário de trabalho e tecnologia. Porto Alegre, RS: Zouk.

Toni, M. de. (2003). Visões sobre o trabalho em transformação. Sociologias, 5(9).

Tylor, E. B. (1920). Primitive Culture. London, UK: Printed in USA.

Tolfo, S. D. R., \& Piccinini, V. C. (2007). Sentidos e significados do trabalho: Explorando conceitos, variáveis e estudos empíricos brasileiros. Psicologia E Sociedade, 19(1).

Tolfo, S. D. R., Coutinho, M. C., Almeida, A. D., Baasch, D., \& Cugnier, J. S. (2005). Revisitando abordagens sobre sentidos e significados do trabalho. Anais do Fórum CRITEOS.

Tozatto, M. I. (2009). Feridas no tecido familiar. XVIII Congresso Latino-Americano FLAPAG e X Simpósio CEFAS. Práticas Institucionais na América Latina: Casal, Família, Grupo e Comunidade.

Varikas, E. (1992). Quelques réflexions em vrac a propôs de 1 'usage de "genre", rapports sociaux de sexe ET division sexuelle Du travail. Cahiers Du GEDISST, 3, 55-65.

Venzke, C. S. (2015). Educação para a sustentabilidade e o desenvolvimento docente na Administração (Unpublished doctoral dissertation). Universidade Federal do Rio Grande do Sul, Porto Alegre, RS.

Wigglesworth, C. (2014). SQ21: The twenty-one skills of spiritual intelligence. New York, NY: Select Books.

Zohar, D. (2012). Spiritual intelligence: The ultimate intelligence. London, UK: Bloomsbury Publishing Group. 


\section{AUTHOR NOTES}

Renato K. Colomby, Departamento de Ciências Administrativas, Universidade Federal do Rio Grande do Sul (UFRGS); and Silvia G. da Costa, Departamento de Ciências Administrativas, UFRGS.

Renato Koch Colomby is now PhD Student at the Departamento de Ciências Administrativas of Universidade Federal do Rio Grande do Sul (UFRGS). Silvia G. da Costa is now Associate Professor at the Departamento de Ciências Administrativas of UFRGS.

Correspondence concerning this article should be addressed to Renato K. Colomby, Washington Luís Street, 855, Centro Histórico, Porto Alegre, Rio Grande do Sul, Brazil, CEP 90010-460.

E-mail: renato.colomby@gmail.com

EDITORIAL BOARD

Editor-in-chief

Silvio Popadiuk

Associated Editor

Andrea Oltramari

Technical Support

Vitória Batista Santos Silva
EDITORIAL PRODUCTION

Publishing Coordination

Irina Migliari

Language Editor

Daniel Leão

Editorial Trainee

Maria Luiza Vanz

Layout Designer

Emap

Copyeditor

Irina Migliari
Graphic Designer

Libro 